\title{
バイオオイルの熱エネルギー利用に関する研究 \\ Experimental Study on Thermal Energy Utilization of Bio-Oil
}

\section{正 鳥居 修一（熊本大大学院）}

Shuichi Torii

Kumamoto University, 2-39-1 Kurokami, Chuo-ku, Kumamoto 860-8555

\begin{abstract}
The aim of the present study is to produce the thermal energy of bio oil. Emphasis is placed on the component analysis and temperature measurement of combustion gas, the modification of commercial burner. Here the combustion gas components, i.e., $\mathrm{H}_{2}, \mathrm{O}_{2}, \mathrm{~N}_{2}, \mathrm{CH}_{4}, \mathrm{CO}, \mathrm{CO}_{2}, \mathrm{NOx}$, SOx and $\mathrm{N}_{2} \mathrm{O}$ are measured with the aid of the gas chromatograph. Consideration is given to the effect of bio oil on the concentration of $\mathrm{N}_{2} \mathrm{O}$, NOx and SOx. It is found that (i) the concentration of $\mathrm{N}_{2} \mathrm{O}$ and its production are suppressed by using the bio oil in comparison with the heavy oil, and (ii) no production of NOx and SOx yields in the combustion gases of the bio oil fuel.
\end{abstract}

Key Words: Bio-Oil, Combustion, Renewable Energy, Modified Burner

1.はじめに

石油等の化石燃料は主にエネルギー資源として世界中で さまざまな用途で使用されている。これらのエネルギーは 二酸化炭素をはじめとした環境污染の原因物質を排出し, 膨大な量が消費されており，いずれ枯渴すると危惧されて いる．したがって，石油系資源に代わる再生可能エネルギ 一開発・研究が急務となっている.

化石燃料を燃焼して発生する二酸化炭素による地球温暖 化問題とエネルギー問題を解決する手段の一つとして，力 ーボンニュートラル物質をエネルギー資源として用いる方 法がある.カーボンニュートラル性をもつた然料の一つに 「バイオオイル」がある。バイオオイルは粘度の高い黒い 液体で, トウモロコシの茎や樹皮片といった農業や林業の 廃棄物をはじめ，ほぼすべての有機材を原料とすることが できる再生可能エネルギーである。石油等に代わる代替エ ネルギーとして, 今後実用化に向けた研究が期待されてい る。

一方, 発熱量が原油の半分程度でありエネルギー密度が 低いこと, 常温で粘度が高く流動性が悪いこと, 含水率が 高い点等の性質により，これまで原油を燃料としている市 販の装置にそのまま然料として代替するには問題がある.

また，バイオオイルを燃料として使用するためには，装置 の改良や，重油等の通常使用する燃料に混ぜて使用するな どの工夫が必要になる。

本研究では，バイオオイルの物性值の測定を行い，その データから市販の燃焼装置でバイオオイルのみを燃料とし て連続然焼できるよう燃焼装置を改良し, その燃焼特性に ついての研究を行った。 また, 燃焼温度の測定と, バイオ オイルの燃焼によって生じる排気ガスの成分分析を行うこ とによって，市販の装置でのバイオオイルのエネルギ一利 用の可能性を検討し，バイオオイルの排ガスが環境に与え る影響, エネルギーとして利用する際の最適な操作条件を 明らかにすることを本研究の目的とする。

\section{2. 実験装置および方法}

市販のバーナーを用いてバイオオイルを燃焼させ，その 燃焼ガスの特性や温度を計測するために，図 1 に示寸燃焼 炉を用いた. 炬は燃焼装置, 温度計測用・ガス分析用ポー ト及びサイクロンセパレーターで構成されている。

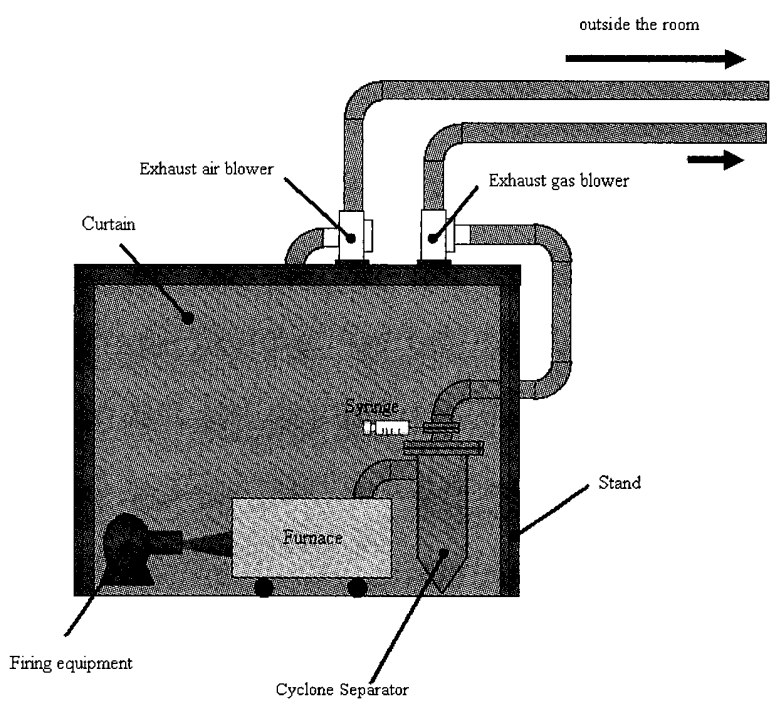

Fig.1 Experimental Setup for Combustion.

バーナー（これを図中では，噴射装置と呼ぶ，以下に詳 細を示す）で燃焼した燃焼ガスは, 燃焼炉内で熱電対によ ってガス温度が計測された後, サイクロンセパレーターで ガス中を浮遊する燃焼灰が回収された後, シリンジで回収 されスクラバーで臭いを除去して大気に放出される.

加熱している各装置の温度, 火炎温度, 燃焼ガス温度を 測定するために，シース被覆された $\mathrm{K}$ 型熱電対を用いた。 火炎温度はノズル噴射軸方向に配置された燃焼炉内の均質 に設置した熱電対によって測定された（図 2）.

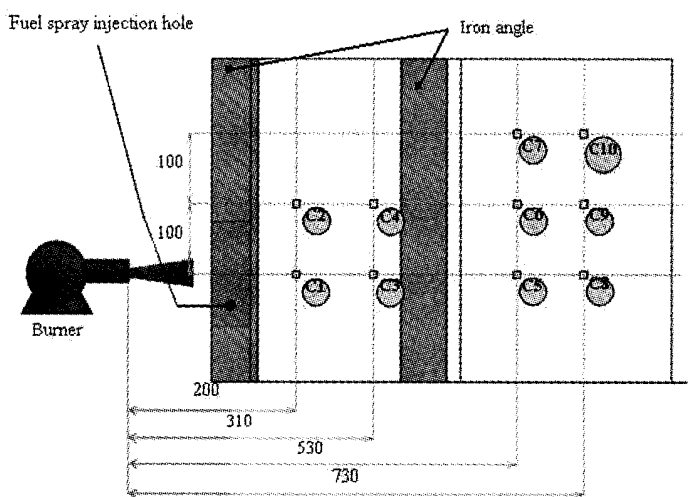

Fig.2 Location of combustion gas temperature measurement. 
燃焼装置として，加藤鉄工バーナー製作所製のパイロッ トガンタイプバーナーを使用した。 そこで, バイオオイル が使用できるように，バーナーを改良した．即ち，然料夕 ンクからギアポンプまで然料の温度が低下するのを防ぐた めに，ホースパイプを保温するだけでなく，その周りをリ ボンヒーターで加熱した。また，バイオオイルが噴射する ノズル及びギアポンプからノズルまでの配管をリボンヒー ターで加熱した。特に，噴射ノズル付近はリボンヒーター で加熱しなければ，バイオオイルは噴射するものの，霧状 にならず液滴で噴射されるだけで着火しない。

燃焼ガスの成分分析はガスクロマトグラフを採用し，測 定装置（GC-8AIT）を使用した。また，NOx，SOx 等のガ ス成分の有無およびその含有量を精度良く測定するため, ポータブルガス分析計を使用した。 ガス分析を行う際，ガ スを採取してガス成分を測定するが，これを 3 回行なった.

\section{3. 実験結果と考察}

バイオオイルが安定然焼する際, 炉内の各測定位置での燃 焼ガス温度推移を図 3 に示す。また，参考までに，対応す る A 重油とバイオディーゼル然料の結果も示す.

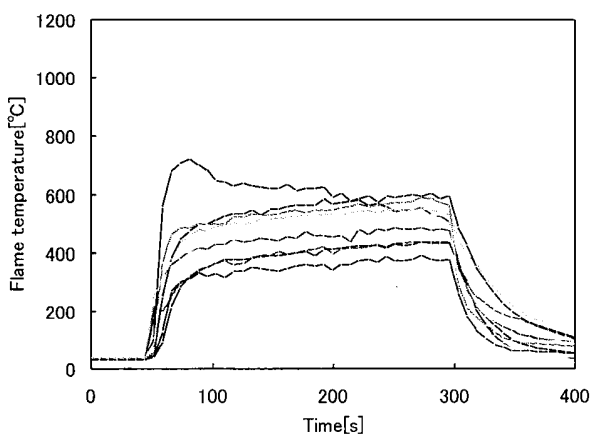

$-\mathrm{C} 1$
$-\mathrm{C} 2$
$\mathrm{C} 3$
$\mathrm{C} 4$
$-\mathrm{c} 5$
$-\mathrm{C} 6$
$-\mathrm{C} 7$
$-\mathrm{C} 8$
$-\mathrm{C} 9$
$\mathrm{C} 10$

(a) Bio-oil

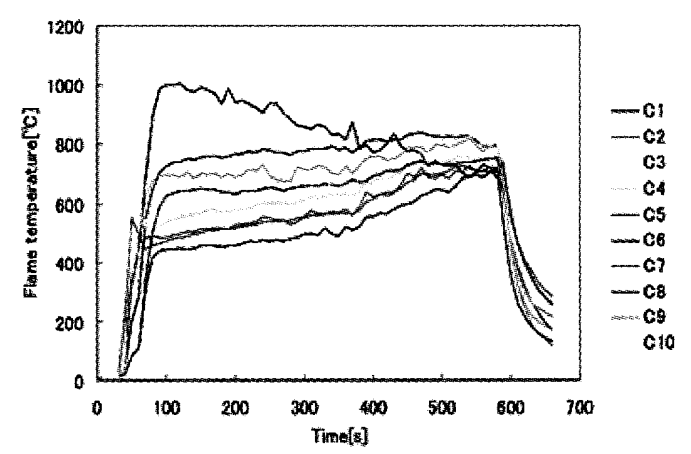

(b) Heavy oil

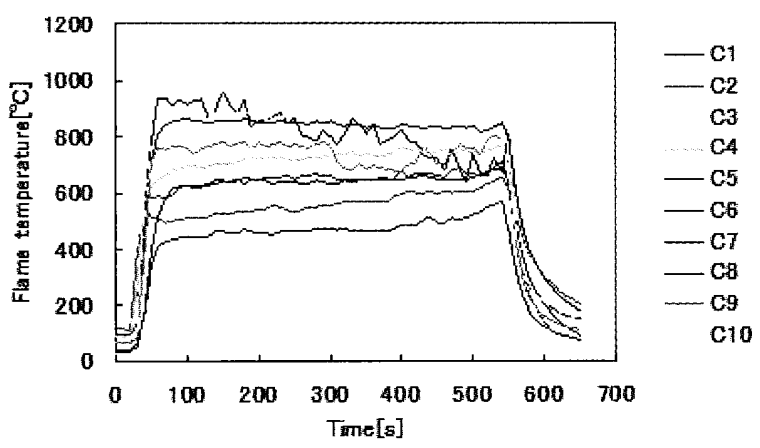

(c) Bio diesel fuel

Fig. 3 Temperature distribution of combustion gas.
$\mathrm{A}$ 重油はおよそ 100 秒から 600 秒にかけて, バイオディー ゼル然料はおよそ 50 秒から 550 秒にかけて,バイオオイル は 50 秒から 300 秒にかけて，それぞれ炉内全域において一 定の温度を保持し, 安定燃焼が確認された。ここで, バイ オオイルの燃焼時間が他の燃料と比較して短かったのは, 然料タンクへの然料投入量が少なかったためである.また， $\mathrm{A}$ 重油, バイオディーゼル然料の温度推移の定常性と, バ イオオイルのそれとを比較しても, 有意の差はなく, バイ オオイルが通常使用する然料と同じように使用できること が分かった。ただし，最高温度に関しては，A 重油と比較 すると $300^{\circ} \mathrm{C}$ 程度低く, 全体的な火炎温度も低くなってい る.これはバイオオイルの発熱量が， $\mathrm{A}$ 重油のそれよりも 半分程度であることによると考えられる。

バオオイルの燃焼ガス成分の分析結果を表 1 に纒める.

Table 1 Combustion gas components of Bio-oil.

\begin{tabular}{|c|c|c|c|c|c|c|c}
\hline & \multicolumn{7}{|c}{ components [\%] } \\
\cline { 2 - 8 } & $\mathrm{H}_{2}$ & $\mathrm{O}_{2}$ & $\mathrm{CH}_{4}$ & $\mathrm{~N}_{2}$ & $\mathrm{CO}_{2}$ & $\mathrm{~N}_{2} \mathrm{O}$ & $\mathrm{CO}$ \\
\hline 1 & 0.0882 & 9.558 & 0.4870 & 71.17 & 12.95 & 0.1723 & 0.0000 \\
\hline 2 & 1.4656 & 8.657 & 0.5988 & 71.14 & 11.17 & 0.1032 & 0.0000 \\
\hline
\end{tabular}

\begin{tabular}{|c|c|c|c|c|}
\hline \multirow{2}{*}{} & \multicolumn{4}{|c|}{ components [ppm] } \\
\cline { 2 - 5 } & $\mathrm{NO}_{2}$ & $\mathrm{SO}_{2}$ & $\mathrm{NO}$ & $\mathrm{H}_{2} \mathrm{~S}$ \\
\hline 1 & 0 & 0 & 1 & 0.2 \\
\hline 2 & 0 & 0 & 1 & 0.1 \\
\hline
\end{tabular}

一般的に，バイオ燃料を燃焼させた際，一酸化二窒素 $\left(\mathrm{N}_{2} \mathrm{O}\right)$ の発生が指摘されている。一酸化二窒素は温室効 果ガスとして知られているが，殆どのその効果 (影響) を 指摘されることはない。一酸化二窒素の温室効果は二酸化 炭素より 100 倍以上高いのであるが，そのことが注目され ることはない，それは絶対的な排出量が二酸化炭素に比較 して極端に低いためである.バイオ燃料を使用すること(カ 一ボンニュートラル）は，地球温暖化の抑制効果（二酸化 炭素排出抑制効果）になるのであるが，生物由来の媒体は 多くの窒素を含んでいる関係で，媒体が然焼する過程で酸 化されることで $\mathrm{N}_{2} \mathrm{O}$ が発生する，バイオオイルは $\mathrm{N}_{2} \mathrm{O}$ の 発生が低く抑えられていることが分かった。また NOx, SOx が発生していないこともバイオマス燃料特有の特徵と言え る.硫黄分がバイオオイルには $\mathrm{A}$ 重油 ${ }^{(1)}$ と比較して少なく, これはSOx が発生しにくい要因と考えられる.

\section{4.まとめ}

市販のバーナーを改良し，バイオオイルを燃料とした然 焼させる実験を行い有用な結果が得られたので，以下にま とめる。

(1) バイオオイルを燃料とした専用の燃焼装置を使用し なくても, 既存のバーナーを部分的に多少改良するこ とで,バイオオイルを燃料として使用できる.ただし， その使用に際しては, バイオオイルの特性から，メン テナンスに注意が必要である。

（2）着火させるために，ノズル付近を加熱して噴霧化を促 進しなければならない。また，火炎温度は，通常の燃 料を使用した時よりも最高温度は $200 \sim 300^{\circ} \mathrm{C}$ ぼ低 <, 平均火炎温度も低い.

（3）バイオオイルは $\mathrm{N}_{2} \mathrm{O}$ の発生が低く抑えられ, NOx, SOx が発生しにくい.

参考文献

(1) 機械工学便覧 基礎編 $\alpha 5$ 熱工学、日本機械学会 